\title{
Effectiveness of energy renovations: a reassessment based on actual consumption savings
}

\author{
Faidra Filippidou (1D • Nico Nieboer • Henk Visscher
}

Received: 20 October 2017 / Accepted: 16 February 2018 / Published online: 7 March 2018

(C) The Author(s) 2018. This article is an open access publication

\begin{abstract}
Energy renovations offer unique opportunities to increase the energy efficiency of the built environment and for the existing housing stock; they are the most important solution. Usually, energy savings are based on modeling calculations. However, recent research has shown that the predicted energy consumption differs largely from the actual consumption. In this paper, the effectiveness of energy measures is reassessed based on actual consumption data. We use a monitoring system, which contains information about the energy performance of around $60 \%$ of the Dutch non-profit housing sector (circa 1.2 million dwellings). We connect the data from this monitoring system to actual energy consumption data from Statistics Netherlands on a dwelling level. Using longitudinal analysis methods, from 2010 to 2014, we are able to identify the energy efficiency improvements of the stock and determine the effectiveness of different measures in terms of actual energy savings. The results reveal the actual energy savings of different efficiency measures and highlight the significance of the actual energy consumption when a renovation is planned or realized.
\end{abstract}

\footnotetext{
F. Filippidou $(\bowtie) \cdot N$. Nieboer $\cdot$ H. Visscher

Faculty of Architecture and the Built Environment, OTB, Delft

University of Technology, Julianalaan 134, 2628 BLDelft,

The Netherlands

e-mail: f.filippidou@tudelft.nl

N. Nieboer

e-mail: n.e.t.nieboer@tudelft.nl

H. Visscher

e-mail: h.j.visscher@tudelft.nl
}

Keywords Energy renovations $\cdot$ Monitoring $\cdot$ Energy savings $\cdot$ Energy efficiency $\cdot$ Non-profit housing · Building energy epidemiology

\section{Introduction}

The existing housing sector plays an important role towards achieving the energy efficiency targets worldwide and in the European Union (EU) (European Commission 2016a; SER, 2013; ürge-Vorsatz et al. 2007). The energy performance of buildings is so poor that the sector is among the most significant $\mathrm{CO}_{2}$ emission sources in Europe (BPIE 2011). Existing buildings account for approximately $38 \%$ of the final energy consumption in the European Union (EU), and are responsible for $36 \%$ of the $\mathrm{CO}_{2}$ emissions (European Commission 2008 and 2014 ). A large percentage of this energy consumption is assigned to the residential sector. On average, households consume $24.8 \%$ of the total energy consumption in the EU (Eurostat 2016).

Energy renovations in existing dwellings offer unique opportunities for reducing the energy consumption and greenhouse gas emissions. Energy renovation is instrumental for reaching the EU and national 2020 goals (Saheb et al. 2015). It has implications for growth and jobs, energy and climate, as well as cohesion policies. Renovating existing buildings is a "win-win" option for the EU economy (Saheb et al. 2015). Although there have been various energy renovation actions of dwellings in Europe and the Netherlands, the assessment and monitoring of the savings achieved is 
insufficient. Monitoring the energy improvements of the existing housing stock can provide valuable information, concerning the energy savings that can be achieved both in terms of actual and predicted energy consumption. The patterns of the predicted energy reduction in most cases differ from the actual energy consumption (Balaras et al. 2016; Filippidou et al. 2016; Majcen et al. 2013; Tigchelaar et al. 2011). Predicted or modeled energy consumption can differ from the actual consumption by as much as $50 \%$ less or $30 \%$ more in dwellings (Majcen et al. 2016). Previous research (Balaras et al. 2016; Majcen et al. 2013; SunikkaBlank and Galvin 2012) has highlighted the performance gap - the difference between predicted and actual energy consumption, in different building stocks. The focus on actual consumption is increasing, and studies on the gap between the predicted and actual energy consumption of buildings start to appear in Europe.

This paper examines the impact of thermal renovation measures on both the predicted and actual energy consumption of the renovated non-profit stock in the Netherlands. The actual savings reveal the true effect of renovations on the reduction of energy consumption and highlight the impact of (combinations of) measures on the dwellings' performance. We analyze the energy saving measures (ESMs) realized and their impact on the actual and predicted energy consumption. In the following background "Energy Renovations and Savings," we discuss energy renovation concepts and definitions. "Data and Methods" focuses on the data and research methods used. In "Results and Discussion," we present the results of the analysis, and we draw conclusions based on the outcomes of the research in the "Conclusions" section.

\section{Energy renovations and savings}

Throughout Europe, national approaches to building stock monitoring have evolved separately. Information about the progress of energy performance improvements is not only needed to track the progress of policy implementation (Boermans et al. 2015) but better information and data are necessary to help develop roadmaps in order to achieve more energy efficient buildings (BPIE 2011).

The 2012 Energy Efficiency Directive (EED) and the 2010 Energy Performance of Buildings Directive (EPBD) are the EU's main legislation for the reduction of the energy consumption in buildings. In article 4 of the EED, Member States are required to establish longterm strategies for mobilizing energy renovations in their building stocks (BPIE 2014). A recent evaluation of the EED (BPIE 2014; European Commission 2016b) found that energy renovation plans or guidelines are still lacking in identifying the most effective measures for each climate, country (according to its national energy regulations), type of dwelling, size, age, operation, and maintenance, dwelling envelope, and many more. On top of this, there was no clear definition of the term energy renovation at a European level, thus, making the implementation of ESMs more difficult.

The energy savings potential of the existing dwellings is large. In the Netherlands, policy measures have been employed since the last quarter of the twentieth century, mainly through building codes and standards. The energy consumption of new buildings has been regulated since 1975 consisting of limits on transmission losses based on insulation values (Boot 2009). In 1995, these limits were expanded to include the national "EPC" (Energy Performance Coefficient) which is a figure expressing the energy performance of a building depending on the energy demand for space heating, hot water, lighting, ventilation, humidification, and cooling. The energy performance of the existing housing stock is being regulated through energy labels (A to G-most efficient to least efficient), since 2008, when the EPBD was implemented in the Netherlands. The average energy label in 2015 was C (RVO 2015). As the years pass, more dwellings adopt an energy label and thus far 2.9 million have one. The majority of these dwellings belong to the rental sector. Figure 1 presents the distribution of the energy labels of the non-profit housing stock for four different years (2010-2014). In the first column of the graph (A label), the $\mathrm{A}+$ and $\mathrm{A}++$ labels are also included. It is clear that there is a tendency towards an increasing performance through the years. The labels denoting a relatively inefficient home (D, E, F, and G) show a decline through the years, whereas the "higher" efficiency labels (A, B, C) show an increase.

Energy regulations regarding the existing stock are usually less strict than those regarding new buildings; whereas from 2020, nearly zero energy standards must be achieved. Nevertheless, the energy performance of the existing stock is of crucial importance, especially taking into account the low and declining construction rates in the EU (Pombo et al. 2016; Thomsen and van der Flier 2002; Filippidou et al. 2017). Renovating 


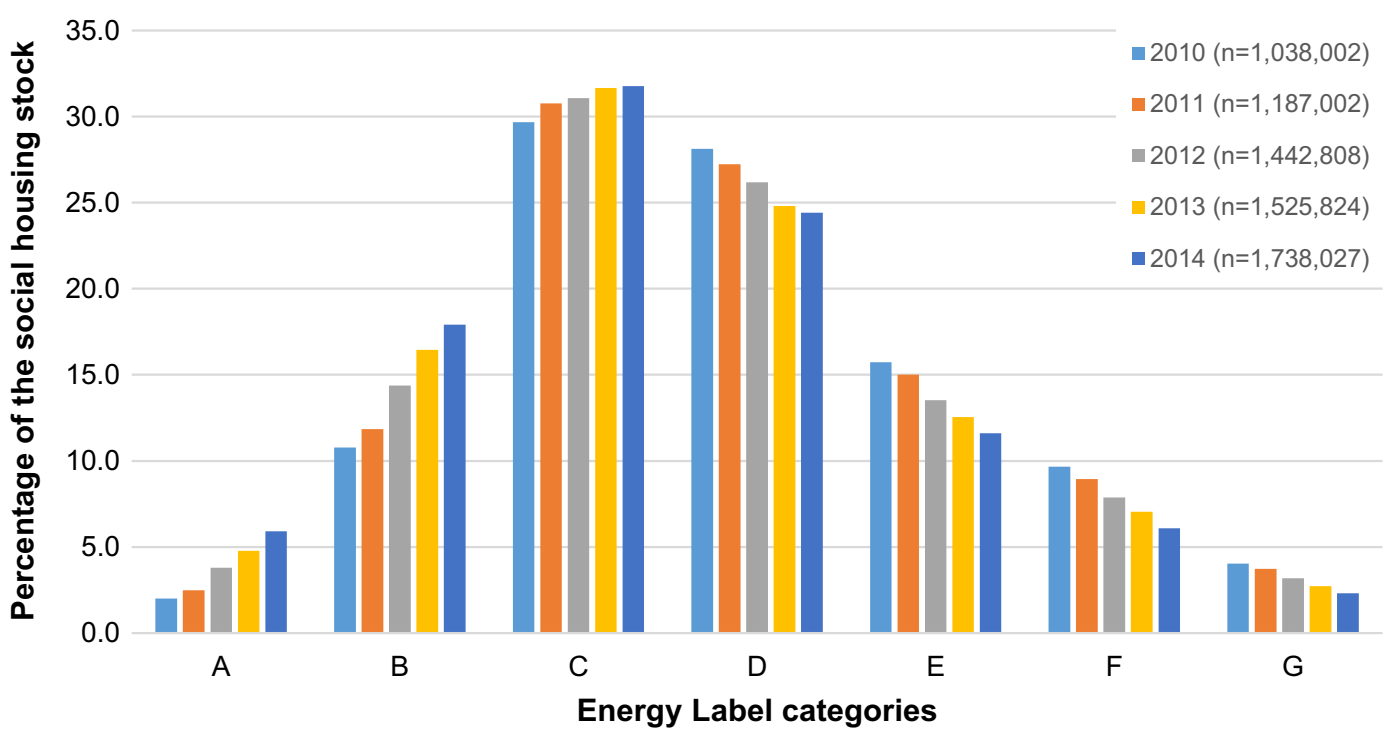

Fig. 1 Energy label distribution in the non-profit housing stock 2010-2014 (Filippidou et al. 2017)

existing buildings is seen as a "win-win" option for the EU economy (Saheb et al. 2015). However, there are challenges mainly relating to the financing, market uptake, and occupant awareness of energy renovations. Further, although there have been various energy renovation actions of dwellings in Europe, the assessment and monitoring of these renovations is lacking.

New buildings and major renovations in the Netherlands are required to meet specific standards, e.g., $R_{\mathrm{c}}$ values of floors, façades, roofs, and $U$ values of windows, as of January 2015 (van Eck 2015). In addition, the term major renovation is used for dwellings where more than $25 \%$ of their envelope area is renovated (van Eck 2015), which is in accordance to the 2010 recast of the EPBD (European Parliament, Council of the European Union 2012). Only minimum insulation standards are applied for minor renovations or isolated ESMs, without an energy performance calculation being necessary (van Eck 2015).

Research on the energy renovations of dwellings usually focuses on selected cases (exemplary buildings) or case studies (Khoury et al. 2016; Mastrucci et al. 2014) except for a few dealing with epidimiological methods (Hamilton et al. 2017). Up to now, and due to the difficulty of acquiring actual energy consumption data on big datasets, much of the research performed focused on the predicted energy savings of renovated building stocks (Ballarini et al. 2014; Mata et al. 2013). In practice, the situation is similar with most professionals using the predicted energy savings as a reference for future renovations. However, based on outcomes of both the research on the performance gap and on the energy renovations, the impact of these renovations on the actual energy consumption is expected to be significantly different. Previously published research conducted on the social housing stock of the Netherlands on isolated energy renovation measures by Majcen et al. (2016) found several discrepancies between the predicted and actual energy savings, of single efficiency measures, ranging from 0.58 (ratio of actual/predicted savings) to 2.5. Filippidou et al. (2016) describe the annual frequencies of seven renovation measures in the Netherlands. Using an energy performance monitor, they analyze the energy efficiency measures realized in the non-profit housing sector and the impact on the energy performance of the dwellings.

There are several definitions of which measures constitute an energy renovation and the different levels of one. The term "renovation" is used to cover modernization, retrofit, restoration, rehabilitation, and renovation actions that go beyond mere maintenance of the building stock (Meijer et al. 2009). According to the European Commission, there are three types of energy renovations: the implementation of single measures (including the low-hanging fruit), the combination of single measures (which can be termed "standard renovation"), and the deep or major energy renovation-referring to renovations that capture the full economic energy efficiency potential of improvements (European Commission 2014). Still, the definitions of 
a standard or deep renovation are vague. In this paper, we will examine renovated dwellings based on single energy saving measures (ESMs) and combinations of ESMs, which can either be standard or deep renovations.

\section{Non-profit housing sector}

The tenure mix of dwellings is an important factor for the ability to renovate regarding both the energy performance and the impact on the pace of energy renovations. The total amount of dwellings in the Netherlands is 7.5 million. The owner occupied sector amounts to $55.8 \%$ of the total, whereas the rental sector comprises $43.5 \%$ of the total (BZK 2016b). The ownership type is unknown for the remaining $0.7 \%$ (BZK 2016b). The vast majority of the rental sector belongs to housing associations forming the non-profit housing sector. In this paper, we focus on the Dutch non-profit housing. This sector comprises approximately 2.3 million homes, which adds up to $30 \%$ of the total housing market (BZK 2016a). Figures 2 and 3 present a comparison of the non-profit housing stock and the national housing stock in terms of the building year, first, and the typology of dwellings. When considering the building year, we can observe that the non-profit housing stock is similar to that of the total stock. This is more or less also true when we distinguish single-family and multifamily homes; the non-profit housing stock comprises of $53 \%$ multi-family dwellings, the national housing stock of $47 \%$. Figure 3 shows, however, that this similarity cannot be stated about the specific type of dwelling.

We examine the non-profit rented housing stock of the Netherlands, also referred to as social housing, where a significant amount of data are available, for three reasons. First, the non-profit housing sector in the Netherlands is the largest in Europe, having a share of $30 \%$ of the total stock as mentioned above. This fact advances the research, providing the opportunity to work on a representative sample of the national housing stock, in terms of typology. Second, having such an extensive and representative sample of dwellings is a stepping-stone for the provision of statistically significant results. Last, the non-profit housing sector is making decisions about energy efficiency and sustainable solutions collectively and is being subsidized by the state for goals promoting the energy neutrality of the country (Filippidou et al. 2017). Thus, the results of this study can serve as an indication of the energy renovation in the Dutch housing stock, while also considering the differences of the stocks, as mentioned above.

Although no common definition for the non-profit housing sector is used, three elements are shared across the European non-profit social housing sectors: a mission of general interest, ${ }^{1}$ affordable housing for the lowincome population, and realization of specific targets, defined in terms of socio-economic status or the presence of vulnerabilities (Braga and Palvarini 2013). Nonprofit housing is typically owned by the public sector; however, there is an increasing trend towards non-public involvement or the privatization of the non-profit housing sector in Europe, as is the case in Ireland, UK, Austria, France, and Denmark (Filippidou et al. 2017). Since the beginning of the 1990s, the Dutch non-profit housing sector deviated from government control and public financing and became a financially independent sector. In the Netherlands, non-profit housing is almost entirely in the hands of private organizations (Elsinga and Wassenberg 2014; Priemus 2013; Kemeny 2002). These organizations can be better described as "hybrid"- they act between government, market, and community (Nieboer and Gruis 2016). They have to manage the different and frequently competing interests from each of these three entities (Nieboer and Gruis 2016). The housing organizations have to fulfill several mandatory goals regarding the provision and allocation of homes.

Energy savings and sustainability are prominent on the agenda of the non-profit housing sector, especially since 2008, as part of the EPBD implementation in the Netherlands (Aedes 2016). The main energy efficiency policy for the sector is described in the Energy Saving Covenant for the Rental Sector ("Convenant Energiebesparing Huursector" 2012). The current aim of the non-profit housing sector is to achieve an average energy performance indicator, called Energy Index (EI), of 1.25 , corresponding to an energy label $\mathrm{B}$, by the end of 2020 (BZK 2014). The Covenant is a voluntary agreement between Aedes - the umbrella organization of housing associations - the national tenants union, and the national government. The goal of the agreement

\footnotetext{
${ }^{1}$ Service of general interest (SGI), SGIs are services that public authorities of the Member States classify as being of general interest and, therefore, subject to specific public service obligations (PSO). The term covers both economic activities and non-economic services. The latter are not subject to specific EU legislation and are not covered by the internal market and competition rules of the Treaty. (European Commission 2011)
} 


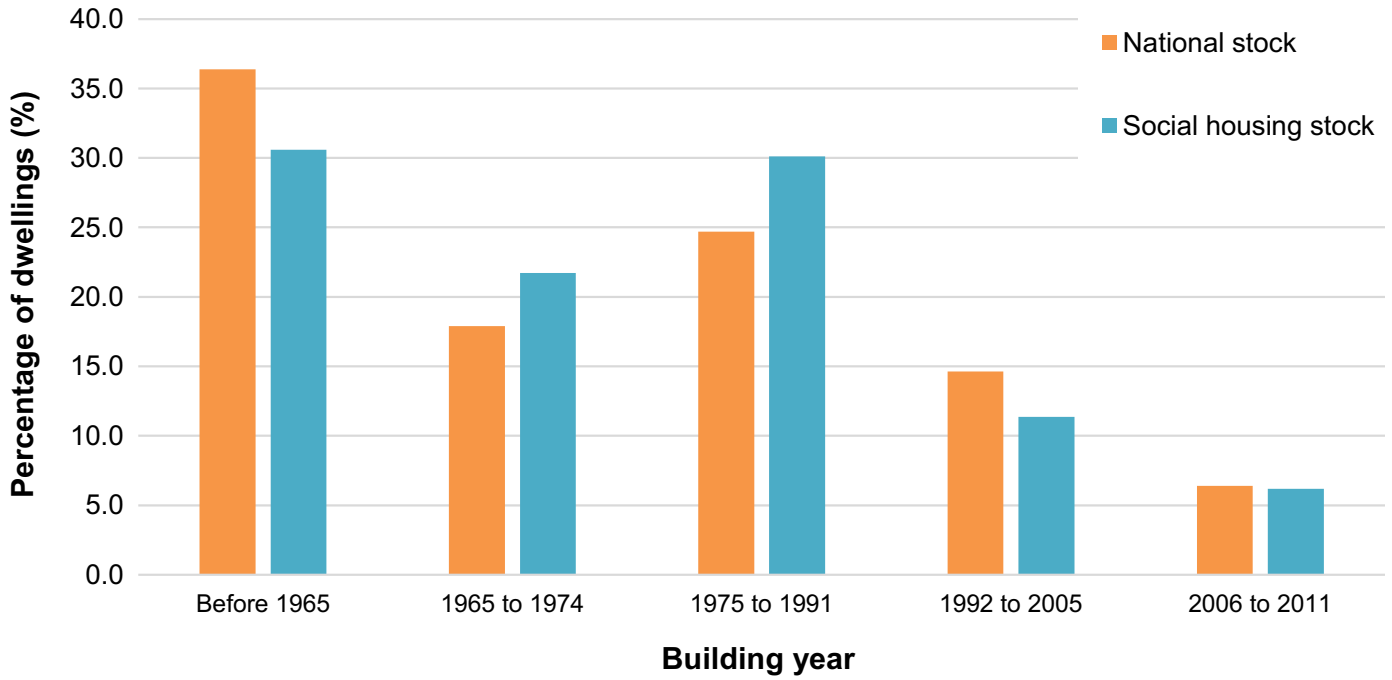

Fig. 2 Comparison of building year cohort distribution between the national and social housing stock (source: RVO 2011 and SHAERE database)

corresponds to a reduction of 33\% in energy consumption compared to the 2008 levels (BZK 2014). This voluntary agreement is a promising example of policy implementation in organized housing. Agreements like the Covenant could be enforced in communities and other public or private bodies to ensure energy efficiency of housing stocks. However, the application of such agreements is difficult in the owner-occupied housing sector where the owner bears the energy efficiency investment weight alone and is difficult to motivate (Filippidou et al. 2017).

\section{Data and methods}

This study includes an inventory of ESMs of the nonprofit rented stock in Netherlands from 2010 to 2014. Moreover, we examined the effectiveness of these

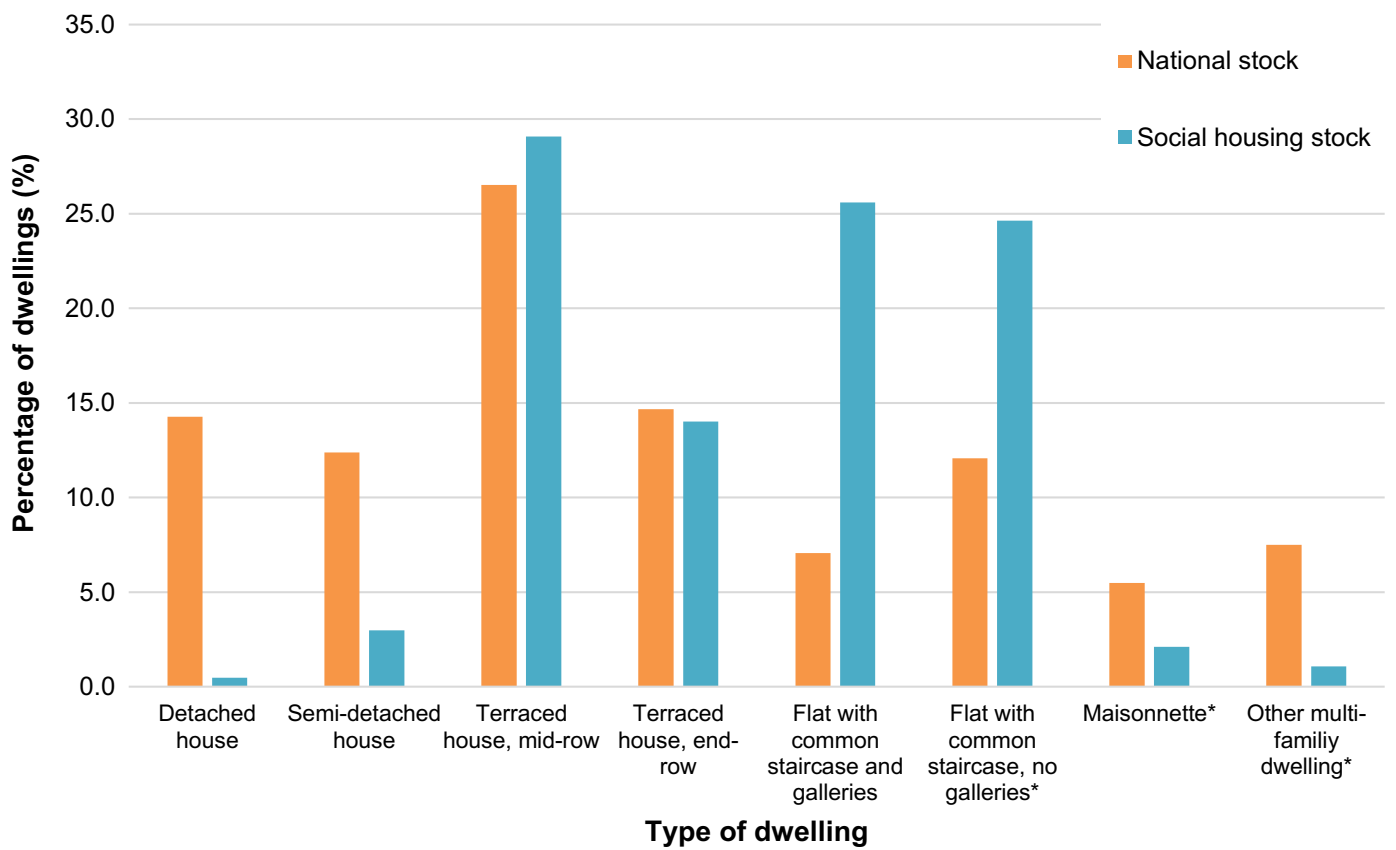

Fig. 3 Comparison of type of dwelling cohorts' distribution between the national and social housing stock (source: RVO 2011 and SHAERE database) 
measures based on actual and predicted energy savings as annual values between 2010 and 2014. In the Netherlands, $85 \%$ of households are heated with natural gas (ECN 2015). Less than 1\% of dwellings use electric heaters in the non-profit housing stock. Previous research, on the energy saving measures in the Dutch non-profit housing stock, shows no change towards electrical heaters (Filippidou et al. 2016). Thus, for the purposes of this study, we focus on the gas consumption data. We used two different datasets to achieve the identification of the measures and examine their effectiveness. In both datasets, an encrypted identifier variable for each dwelling is used, comprising of the address, postcode, and housing number.

\section{Data}

First, we used the SHAERE database ("Sociale Huursector Audit en Evaluatie van Resultaten Energiebesparing"-in English, Social Rented Sector Audit and Evaluation of Energy Saving Results). SHAERE is the official tool for monitoring the progress in the field of energy saving measures for the non-profit housing sector. SHAERE is the first monitoring database of the energy efficiency evolution of the building stock in the Netherlands with microdata information, on a dwelling level. It includes information on the dwellings' geometry, envelope, installations characteristics, and the predicted heating energy consumption based on ISSO publication 82.3 (ISSO 2009). In more detail, the data include the $U$ values (thermal transmittance, $\mathrm{W} / \mathrm{m}^{2} \mathrm{~K}$ ) and $R_{\mathrm{c}}$ values (thermal resistance, $\mathrm{m}^{2} \mathrm{~K} / \mathrm{W}$ ) of the envelope elements, the type of installation for heating, domestic hot water (DHW) and ventilation, and the predicted energy consumption. The data is categorized as variables per dwelling. It is a collective database in which the majority of the housing associations participate (Filippidou et al. 2015). This monitor became operational in 2010. Housing associations report their stock at the beginning of each calendar year accounting for the previous year (e.g., in January 2014 reporting for 2013) (Aedes 2016). The participation of housing associations is voluntary, resulting in the variation of the amount of dwellings included in the database each year. On average, more than $50 \%$ of the population of non-profit dwellings is reported each year. The associations report the energy status of their whole dwelling stock using two specific software (Aedes 2016 and Tigchelaar 2014), whose basis is the Dutch energy labeling methodology (ISSO 2009). The database includes data from 2010, 2011, 2012, 2013, 2014, and 2015 , on the performance of the stock in the form of energy certificates. Table 1 presents the number of dwellings reported in SHAERE every year.

Second, we matched the data from SHAERE database, on microdata level, to the actual energy consumption data, which is collected by Statistics Netherlands from energy companies. Both databases include an identification variable for each dwelling based on its address (encrypted). This fact enables us to couple the dwellings from SHAERE to the Statistics Netherlands actual consumption dataset. The actual energy consumption data is collected by energy companies since 2009 . The companies report the billing data, which are calculated on the basis of the dwellings' meter readings annually. In order to compare the data of the predicted heating gas consumption and the actual gas consumption from the Statistics Netherlands, a degree day correction factor to the 2620 heating degree days of the energy labeling method was applied. The Statistics Netherlands data correspond to every year in the period 2009-2014.

The analysis is based on longitudinal data using the identifier variable to follow the energy saving measures of the dwellings. In order to identify the ESMs, we follow and examine seven ESM variables. These include heating system (type and efficiency), domestic hot water system (type and efficiency), ventilation system (type), floor insulation $\left(R_{\mathrm{c}}\right.$ value), roof insulation ( $R_{\mathrm{c}}$ value), façade insulation $\left(R_{\mathrm{c}}\right.$ value), and type of glass ( $U$ value). The ESMs are defined as a change in one or more of the ESM variables. In the following subsection of Methods, "Renovated dwellings," more details for the selection of the renovated cases are described.

Table 1 Number of dwellings reported in SHAERE per year

\begin{tabular}{lll}
\hline $\begin{array}{l}\text { Year of } \\
\text { reporting }\end{array}$ & $\begin{array}{l}\text { Amount of individual } \\
\text { dwellings reported }\end{array}$ & $\begin{array}{l}\text { Percentage of the } \\
\text { total stock }\end{array}$ \\
\hline 2010 & $1,132,946$ & $47.2 \%$ \\
2011 & $1,186,067$ & $49.4 \%$ \\
2012 & $1,438,700$ & $59.9 \%$ \\
2013 & $1,448,266$ & $60.3 \%$ \\
2014 & $1,729,966$ & $73.7 \%$ \\
2015 & $1,374,095$ & $59.7 \%$ \\
\hline
\end{tabular}


Methods

\section{Selection of cases}

The initial dataset from SHAERE comprised $2,189,591$ dwellings containing records from 2010 to 2015. Data filtering was required from the beginning of the data analysis and especially when we coupled the SHAERE dataset to the actual energy consumption dataset of the Statistics Netherlands. The maximum amount of records per dwelling can be six (2010-2015). 1,794,415 dwellings, $82 \%$ of the initial records, were coupled on an address basis with the actual energy consumption data from the Statistics Netherlands. After the double cases control, 1,752,427 $(76.2 \%$ of population) unique dwellings formed the dataset.

In continuity, we performed different controls for dwellings' missing data on gas, electricity, and district heating consumption. 45,625 (2.6\%) cases were excluded. Also, the cases with district heating had to be eliminated due to lack of individual metering - 92,545 $(5.3 \%)$ cases were removed. The number of cases forming the dataset at this point was $1,706,775(74.2 \%$ of population).

Furthermore, we removed the dwellings that had unrealistic values of gas consumption $(<15$ and $>$ $6000 \mathrm{~m}^{3}$ ). We also eliminated dwellings with default set values in all variables and with unrealistic useful living area (when $<15$ or $>800 \mathrm{~m}^{2}$ ) $1,602,391$ cases remained. The boundaries are based on the distribution of the gas consumption and living area variables-we exclude outliers and illogical values. We, then, selected the dwellings with records both in 2010 and 2014. Dwellings that were renovated in 2014 or 2015 had to be excluded, as the actual gas consumption data are available until 2014. The final dataset comprised 650,460 dwellings.

\section{Renovated dwellings}

The goal of this paper is to examine the impact of thermal renovation measures on both the predicted and actual energy consumption of the renovated non-profit stock in the Netherlands. Throughout the paper, we focus on the renovated stock. For this reason, we applied the following method in order to select the renovated stock through the ESM variables.

The insulation variables are based on the thermal resistance $\left(R_{\mathrm{c}}\right.$ value), the glazing on the thermal transmittance ( $U$ value), and are numerical variables. However, in order to identify the improvements of the ESMs, the categorization of the insulation and glazing variables was necessary. The values and boundaries used to distinguish between the levels of insulation derive from the Dutch ISSO publication 82.3 and are presented in Tables 2 and 3 (ISSO 2009). By creating the categorical variables, we were able to identify any improvements of the envelope insulation, in this case ESMs, through the yearly reports. The installation variables (heating system, DHW and ventilation) are already categorical. These seven categorical variables form the group of thermo-physical ESMs examined in this paper.

We, then, create seven variables indicating the improvement of one of the seven ESM variables. These change variables show the improvement or not of each ESM variable (dichotomous variables). We go on creating a single "number of ESM" variable to indicate the number of measures applied in each dwelling. The minimum value of this variable is 0 , suggesting that the dwelling belongs to the non-renovated stock, and the maximum is 7 , suggesting that a complete renovation was realized.

\section{Non-renovated dwellings}

As mentioned above, the goal of this paper is to determine the impact of thermal renovation measures on both

Table 2 Insulation categories for floor, roof, and façade based on the ISSO publication 82.3 (ISSO 2009)

\begin{tabular}{llll}
\hline Characterization & $R_{\mathrm{c}}$ value floor $\left[\mathrm{W} /\left(\mathrm{m}^{2} \mathrm{~K}\right)\right]$ & $R_{\mathrm{c}}$ value roof $\left[\mathrm{W} /\left(\mathrm{m}^{2} \mathrm{~K}\right)\right]$ & $R_{\mathrm{c}}$ value façade $\left[\mathrm{W} /\left(\mathrm{m}^{2} \mathrm{~K}\right)\right]$ \\
\hline No-insulation & $R_{\mathrm{c}} \leq 0.32$ & $R_{\mathrm{c}} \leq 0.39$ & $R_{\mathrm{c}} \leq 1.36$ \\
Insulation & $0.32<R_{\mathrm{c}} \leq 0.65$ & $0.39<R_{\mathrm{c}} \leq 0.72$ & $1.36<R_{\mathrm{c}} \leq 2.86$ \\
Good insulation & $0.65<R_{\mathrm{c}} \leq 2$ & $0.72<R_{\mathrm{c}} \leq 0.89$ & $2.86<R_{\mathrm{c}} \leq 3.86$ \\
Very good insulation & $2<R_{\mathrm{c}} \leq 3.5$ & $0.89<R_{\mathrm{c}} \leq 4$ & $3.86<R_{\mathrm{c}} \leq 5.36$ \\
Extra insulation & $R_{\mathrm{c}}>3.5$ & $R_{\mathrm{c}}>4$ & $R_{\mathrm{c}}>5.36$ \\
\hline
\end{tabular}


Table 3 Window categories based on the ISSO publication 82.3 (ISSO 2009)

\begin{tabular}{ll}
\hline Characterization & $U$ value window $\left(\mathrm{W} / \mathrm{m}^{2} / \mathrm{K}\right)$ \\
\hline Single glass & $U \geq 4.20$ \\
Double glass & $2.85 \leq U<4.20$ \\
HR+ glass & $1.95 \leq U<2.85$ \\
HR++ glass & $1.75 \leq U<1.95$ \\
Triple insulation glass & $U<1.75$ \\
\hline
\end{tabular}

the predicted and actual energy consumption of the renovated non-profit stock in the Netherlands. However, we need to be certain that an autonomous reduction of energy consumption does not affect the energy savings results of possible energy renovations. For this reason, we also analyze the gas consumption of the nonrenovated dwellings. The selection of this "non-renovated group" of dwellings is based on the single "number of ESM" variable when this takes the value 0 . The dwellings with 0 energy efficiency measures implemented constitute the non-renovated stock.

\section{Actual and predicted energy savings}

Consequently, regarding the savings, we focus on the dwellings that had 0 or at least one ESM realized-i.e., the renovated and the nonrenovated stocks. The coupling of the SHAERE data with the Statistics Netherlands microdata allows us to access the actual gas consumption before and after the ESMs are applied. To calculate the energy savings, we subtracted the gas consumption in 2014 from the one in 2010. This deduction forms the two main variables of this analysis per dwelling - the actual gas savings, where we subtract the actual gas consumption, and the predicted gas savings, where we subtract the modeled gas consumption, as explained by Eqs. 1 and 2. In order to compare the actual and predicted savings, we applied climate correction factors to the gas consumption. The energy label calculation reported in SHAERE assumes 2620 heating degree days (ISSO 2009), therefore, we applied correction factors to the actual gas consumptions supplied by the Statistics Netherlands.

The actual and predicted energy savings are calculated as follows:

Savings $_{\text {actual }}=Q_{\text {actual,before }}-Q_{\text {actual,after }}\left[\mathrm{kWh} / \mathrm{m}^{2} /\right.$ year $]$
Savings $_{\text {predicted }}=Q_{\text {predicted,before }}-Q_{\text {predicted,after }}$

$$
\left[\mathrm{kWh} / \mathrm{m}^{2} / \text { year }\right]
$$

where $\mathrm{Q}_{\text {actual,before }}$ space heating demand before renovation, Statistics Netherlands, Qactual,after space heating demand after renovation, Statistics Netherlands. $\mathrm{Q}_{\text {predicted,before }}$ space heating demand before renovation, calculated according to ISSO 82.3 (ISSO 2009), and $\mathrm{Q}_{\text {actual,after }}$ space heating demand after renovation, calculated according to ISSO 82.3 (ISSO 2009).

This study examines different single ESMs and combinations of ESMs realized in the renovated stock. It also includes the examination of possible savings in the non-renovated stock. In the following, "Results and discussion," section, we present the outcomes from the twofold analysis performed. In the first part, we present the amount of ESMs realized per dwelling and the actual and predicted energy savings achieved based on the number of ESMs. Relatedly, we introduce the type of single and combination ESMs realized in the renovated stock and the actual and predicted savings categorized by the ESMs applied. The single ESMs are based on the change variables, described above in the "Renovated dwellings" sub-section, for the dwellings that only had one ESM realized. But for the dwellings that more than one ESM was realized, we created new variables to identify the combinations of ESMs.

In the second part, in order to explain the gap between the actual and the predicted energy savings, we perform a linear multivariate regression analysis to the renovated stock of the dwellings. Through the regression analysis, we aim to understand the effect of the different single ESMs and how the improvement of the ESMs can be used as predictors and explain the actual and the predicted savings. We used seven independent variables: the seven change dichotomous variables (improvement or not of heating system, domestic hot water system, ventilation, floor insulation, roof insulation, façade insulation, and type of glass). We performed the multivariate analysis for the whole renovated stock on both the actual and the predicted energy savings (as dependent variables). In the following section, the results of the twofold analysis are presented.

\section{Results and discussion}

This section, first, discusses the amount of measures applied per dwelling and the effect of it on the actual 
and predicted energy savings. We then go on introducing the effect of different, single ESMs on the annual energy savings between 2010 and 2014 for the dwellings that had only one ESM realized. We also present the actual and predicted gas consumption of the non-renovated dwelling stock. Furthermore, the effect of various combinations of ESMs on the energy savings is analyzed for the dwellings where more than one ESMs were realized. In the final part of the section, we present the outcomes of the linear multivariate regression.

The mean gas consumption savings in this paper are expressed in kilowatt-hours per square meter and, as a result, are not floor area weighted (for example a dwelling of $500 \mathrm{~m}^{2}$ weighs the same as a $40 \mathrm{~m}^{2}$ apartment). This way, the scale effect is neutralized. We used the Statistics Netherlands dataset to determine the gas consumption pre- and post-renovation. We used the 2009 or 2010 gas data for the pre-renovation values and the 2014 data for the post-renovation consumption values. Groups of dwellings with less than 10 cases could not be exported from the Statistics Netherlands environment for privacy issues and would not be statistically significant. They are, therefore, excluded from the analysis.

The maximum amount of ESMs is 7. Table 4 depicts the amount of dwellings and the number of measures applied per dwelling. The first row depicts the nonrenovated dwellings with 0 measures applied. This group consists of 384,069 dwellings, which is $59.0 \%$ of the sample of this study. According to SHAERE, when we examine the percentage of dwellings with at least one measure (266,391 dwellings), we observe that $16.6 \%$ of dwellings had one measure applied and $15.4 \%$ had two. The amount of measures is larger when the amount of dwellings is smaller, and only $0.1 \%$ of the dwellings had seven measures performed. In $59 \%$ of

Table 4 Number of ESMs realized during 2010-2014

\begin{tabular}{lcc}
\hline Number of ESMs & Frequency (number of dwellings) & Percentage \\
\hline 0 & 384,069 & 59.0 \\
1 & 108,131 & 16.6 \\
2 & 100,211 & 15.4 \\
3 & 35,506 & 5.5 \\
4 & 14,052 & 2.2 \\
5 & 5871 & 0.9 \\
6 & 1967 & 0.3 \\
7 & 653 & 0.1 \\
Total & 650,460 & 100.0 \\
\hline
\end{tabular}

dwellings, no action was taken and these 384,069 dwellings form the non-renovated stock of 2010-2014 (in light gray font in Table 4). $24.4 \%$ of the dwellings had a combination of measures performed, meaning at least two or more ESMs. In the continuity of this paper, we do not focus only on the renovated stock and the ESMs that were applied but we also mention the gas consumption differences of the non-renovated stock.

Figure 4 presents the mean actual and predicted gas savings categorized per number of ESMs and the ratio between mean actual savings and mean predicted savings (except for the 0 ESMs where the predicted savings are 0 ). If the ratio is equal to 1 , there is no gap between actual and predicted savings. A ratio below 1 reveals an overprediction of the actual savings, and above 1 is an underprediction. The left most column of the graph depicts the autonomous gas savings when no ESM has been performed, i.e., the savings of the non-renovated stock. This result has been reported previously in literature as well (Majcen et al. 2016; Filippidou et al. 2016). It is remarkable that in the period of 2010-2014 there has been a reduction of $11 \mathrm{kWh} / \mathrm{m}^{2} /$ year without any energy renovation taking place. Several reasons can explain why, such as possible changes in the method of calculations by the energy companies reporting to Statistics Netherlands (such as a difference of the LHV [lower heating value] of the gas used), possible effects from occupant behavior change or mistakes in reporting in the SHAERE database. It is useful to notice that such a reduction in consumption is only visible from the actual savings and not the predicted. The actual savings difference between 0 and 1 ESM applied is very small, below $2 \mathrm{kWh} / \mathrm{m}^{2} /$ year. In the cases where one ESM was performed, there is almost no gap between actual and predicted gas consumption (ratio $=0.93$ ). However, when 2 or more ESMs have been realized, the models we use over-predict the savings by a factor of 0.66 (actual/predicted ratio) in the case of 2 ESMs to a factor of 0.38 in the case of 7 ESMs. It seems that as the number of measures increases, the gap between actual and predicted savings is also increasing. Moreover, an investment practice is highlighted where the dwellings being renovated are the ones that are in need of such complete renovations. Existing literature supports the fact that the least efficient dwellings do not consume as much as we predict they would (Majcen et al. 2013) and that is also supported by Fig. 4 where the predicted savings of the dwellings with 5, 6, and 7 ESMs are much over-predicted. Nevertheless, the number of measures alone cannot answer the questions set in this 


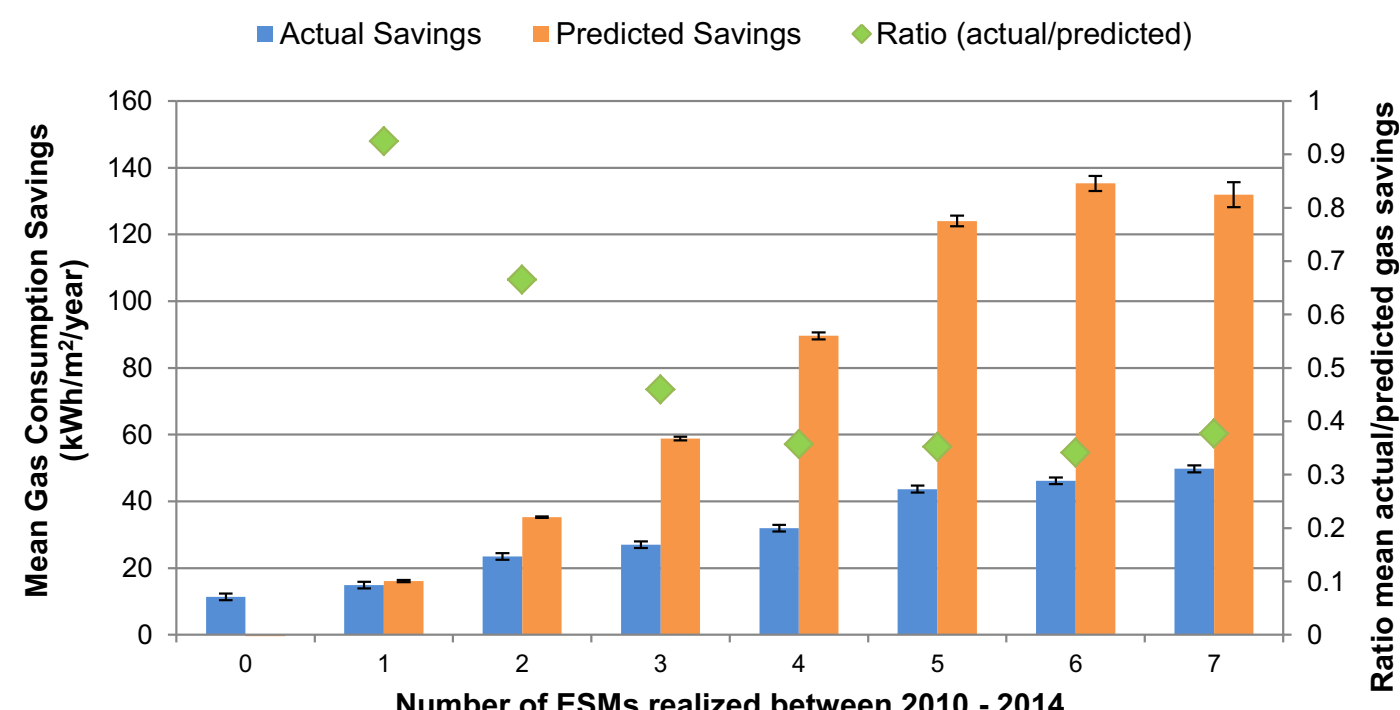

Fig. 4 Mean actual and predicted gas consumption savings based on the number of ESMs realized — including the non-renovated stock (0 ESMs)

study and are presented here to show the general actual versus predicted savings picture. For this reason, we continue the analysis presenting the type of ESMs (both single ESMs and combinations) applied and the impact on the mean actual and predicted gas savings.

108,131 dwellings ( $16.6 \%$ of the sample) had $1 \mathrm{ESM}$ realized between 2010 and 2014. Table 5 depicts the frequency and ratios of mean actual to predicted gas savings of the ESMs. Replacing the heating and DHW systems and glazing are the most popular single ESMs. Figure 5 depicts the effect of these single measures on the actual and predicted savings.

Figure 5 presents the mean actual and predicted savings categorized per type of ESM applied. The dwellings depicted in Fig. 5 are the ones where only one of these ESMs has been performed with the exception of the ESM heating and domestic hot water (DHW) systems because in the Netherlands, in $80-90 \%$ of the cases, the systems are combined. As a result, we also regard the combined change of the heating system and the DHW system as one ESM. This way we present the effect of each individual ESM on the actual and predicted savings. In most cases, the predicted savings are higher than what is actually achieved by a factor of 0.46 to 0.90 (actual/predicted ratio). However, in the case of the heating system change and the ventilation, the actual savings achieved are higher than the predicted. In the case of ventilation, the actual savings are 4.87 (actual/predicted ratio) higher than the predicted ones, which is larger than any other ratio. However, the same air flow rates are assumed by the calculation method for both mechanical and natural ventilation systems. The ESM where the mean actual and predicted savings are almost the same is the floor insulation with a ratio of 1.04. Figure 5 shows that predicted savings are closer to the actual ones for the heating (space heating and DHW) systems and glazing than for the envelope

Table 5 Inventory of ESMs

\begin{tabular}{lcc}
\hline ESMs & Frequency & Ratio mean actual/predicted savings \\
\hline ESM heating system & 18,036 & 1.33 \\
ESM DHW system & 8878 & 0.49 \\
ESM heating and DHW systems & 63,675 & 0.77 \\
ESM ventilation system & 24,934 & 4.87 \\
ESM glazing & 16,521 & 0.90 \\
ESM roof insulation & 10,392 & 0.46 \\
ESM façade insulation & 16,182 & 0.55 \\
ESM floor insulation & 14,414 & 1.04 \\
\hline
\end{tabular}




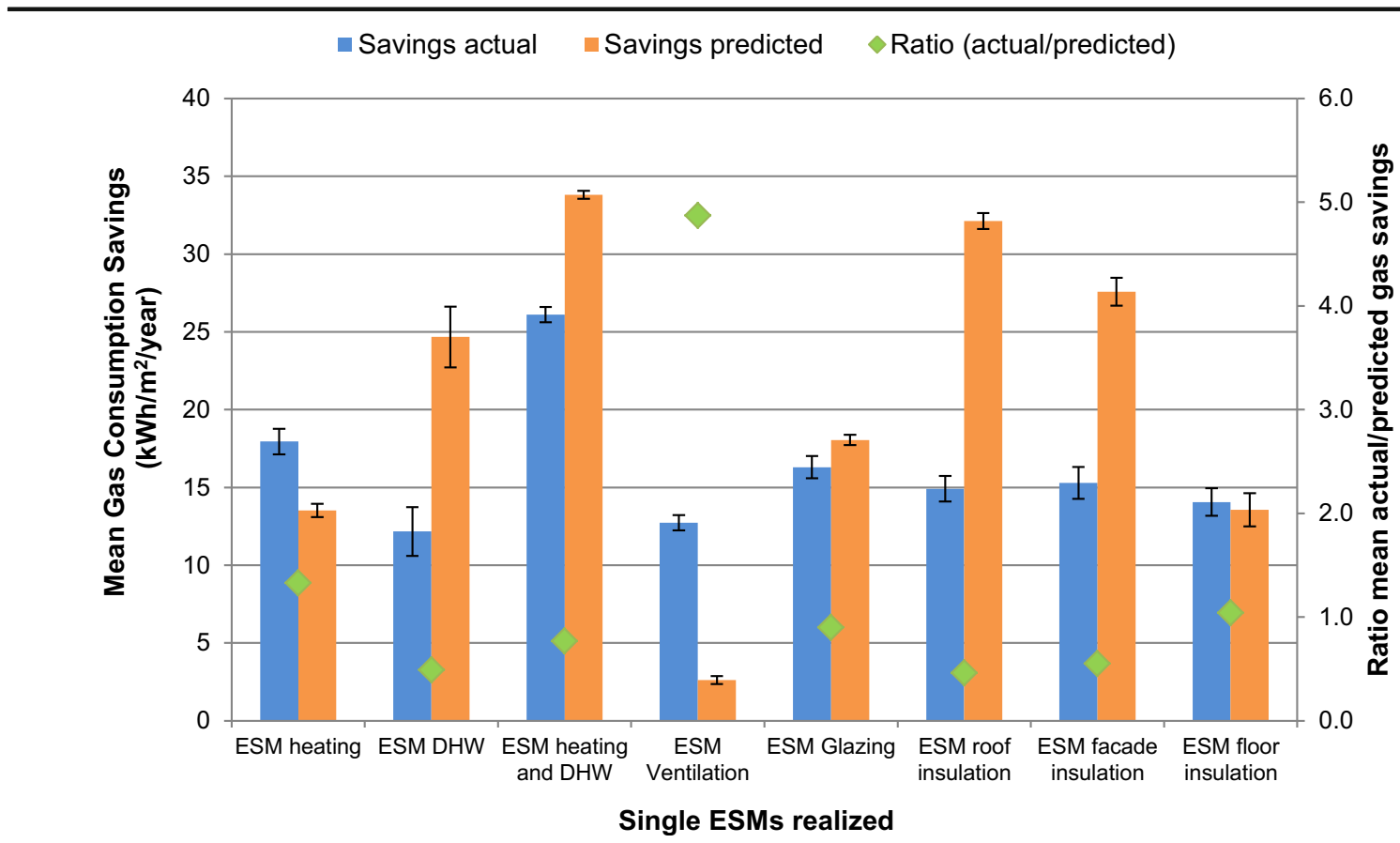

Fig. 5 Mean actual and predicted gas consumption savings for dwellings with single ESMs

insulation ESMs. This phenomenon can be attributed to the fact that most of the old stock's envelope insulation values (façade, roof, and floor) are "simply" based on the regulations in the building year (Rasooli et al. 2016).

While $16.6 \%$ of the dwellings had only one ESM applied, $24.4 \%$ of the dwellings had a combination of ESMs performed, meaning at least two or more ESMs in the period of investigation (2010-2014). We examined a total of 22 different combinations of measures. Table 6 presents the combinations of ESMs studied along with the number of dwellings were each combination has been applied and the ratio of actual to predicted savings.

These combinations of ESMs were based of the frequency of the individual ESMs, the combinations where a standard renovation is depicted (see 5 to 14) and the ones representing deep or more advanced renovations (see 15 to 22). In all cases of the 22 combinations examined, the mean predicted savings are much higher than the mean actual savings achieved.

The combinations of measures in Fig. 6 are depicted in ascending order of the mean actual gas savings. This way we want to highlight both the gap between mean actual/ predicted savings and the difference in actual savings between the combinations of ESMs. The smallest overprediction of the energy savings can be found in the combinations 2 and 3, in comparison to the rest of the combinations. It is our understanding that in the modeled results, in this case the predicted savings, a much more positive picture of the insulation of the dwellings, the energy installation, and the occupant behavior is assumed than what is actually happening. In reality, the synergy of two or more ESMs can prove to achieve less or more actual savings and the gap between the two can be smaller. These results highlight the issue of the gap between actual and predicted energy consumption in terms of savings after renovation measures have been realized. When only the primary heating system is involved, the predicted savings are much closer to the actual (see Fig. 5). Table 6 also depicts the reality of simple combinations of ESMs being realized much more frequently than standard or deeper combinations of ESMs. The results indicate that depending on the mix of ESMs, the ratios are fluctuating as well. The biggest differences occur when 5 or more ESMs are presented (see 16 to 22 in Fig. 6). This may be due to assumed occupant behavior (including indoor temperature and hours of heating system operation) or wrong predictions of the state of the dwelling before an ESM takes place (Balaras et al. 2016; Majcen et al. 2016; Galvin 2014). Moreover, Table 7 and Fig. 7 depict the gap between actual and predicted savings of specific frequent combinations of measures ( 01 and 02 signify the different changes in one ESM).

To examine, in more detail, the effect of the different ESMs on the actual and the predicted savings, we also 
Table 6 Index of combination of ESMs

\begin{tabular}{|c|c|c|c|}
\hline $\begin{array}{l}\text { Index of combinations } \\
\text { of ESMs }\end{array}$ & Combinations of ESMs & Frequency & $\begin{array}{l}\text { Ratio mean actual/ } \\
\text { predicted savings }\end{array}$ \\
\hline 1 & Primary and secondary heating system & 1584 & 0.21 \\
\hline 2 & Heating system and domestic hot water system & 63,675 & 0.77 \\
\hline 3 & Heating system and ventilation & 9256 & 0.72 \\
\hline 4 & Heating system and glazing & 6379 & 0.58 \\
\hline 5 & Heating system and roof insulation & 2993 & 0.35 \\
\hline 6 & Heating system and façade insulation & 5373 & 0.48 \\
\hline 7 & Heating system and floor insulation & 7208 & 0.55 \\
\hline 8 & Heating system, glazing, and roof insulation & 944 & 0.41 \\
\hline 9 & Heating system, glazing, and façade insulation & 2223 & 0.38 \\
\hline 10 & Heating system, glazing, and floor insulation & 1407 & 0.51 \\
\hline 11 & Heating system, ventilation, and glazing & 1835 & 0.53 \\
\hline 12 & Heating system, ventilation, and roof insulation & 577 & 0.30 \\
\hline 13 & Heating system, ventilation, and façade insulation & 2090 & 0.41 \\
\hline 14 & Heating system, ventilation, and floor insulation & 2554 & 0.45 \\
\hline 15 & Heating system, glazing, ventilation, and roof insulation & 490 & 0.29 \\
\hline 16 & Heating system, glazing, ventilation, and façade insulation & 770 & 0.32 \\
\hline 17 & Heating system, glazing, ventilation, and floor insulation & 910 & 0.31 \\
\hline 18 & Heating system, glazing, ventilation, roof, and façade insulation & 417 & 0.32 \\
\hline 19 & Heating system, glazing, ventilation, roof, and floor insulation & 472 & 0.32 \\
\hline 20 & Heating system, glazing, ventilation, roof, floor, and façade insulation & 71 & 0.45 \\
\hline 21 & $\begin{array}{l}\text { Heating system, domestic hot water system, ventilation, glazing, } \\
\text { roof, floor, and façade insulation }\end{array}$ & 642 & 0.38 \\
\hline 22 & Glazing, roof, floor, and façade insulation & 2898 & 0.40 \\
\hline
\end{tabular}

performed two multivariate linear regressions on the renovated stock (266,391 dwellings). Table 8 presents the results of the regressions. The dependent variable for the first regression is the actual savings and for the second regression the predicted savings. The purpose of this regression is not to best understand the factors explaining the savings and the difference between actual and predicted but rather to understand the different weights the ESMs have on them.

The $R^{2}$ of both actual and predicted savings is disappointing. In both regressions, the predictors do not explain sufficiently the savings. That is understandable as we only include the improvement or not (dummies) of the ESMs. In that respect, we focus on the Beta coefficients of the predictor variables as we want to examine the effect of different ESMs on the gas consumption savings as a renovation process. We do not attempt to create a model that will explain in the best way the actual and the predicted savings achieved.

All independent variables are significant for both regression analyses $(p<0.001)$. The independent variables best explaining the actual savings are the improvement of the ESM heating and ESM glazing. We observe the Beta coefficients of these ESMs to be the highest with a positive relationship to the actual savings (Table 8-actual savings). In reality, this means that the change of the heating system and the glazing are affecting the actual savings more positively than other ESMs. The effect is $10.584 \mathrm{kWh} / \mathrm{m}^{2}$ savings for the heating system and $7.262 \mathrm{kWh} / \mathrm{m}^{2}$ for glazing when looking at the B coefficients. The envelope insulation and ventilation ESMs are not affecting the actual savings as much as heating and glazing, based on the Beta coefficients. We could say that a dwelling where heating system and glazing ESMs are applied is expected to achieve higher actual savings.

On the other hand, the independent variables best explaining the predicted savings are ESM roof insulation, ESM façade insulation, and ESM DHW. The Beta coefficients of these ESMs were higher compared to the rest (Table 8-predicted savings). These independent variables do not coincide with the ones explaining the 
- Savings actual $\quad$ Savings predicted $\diamond$ Ratio (actual/predicted)

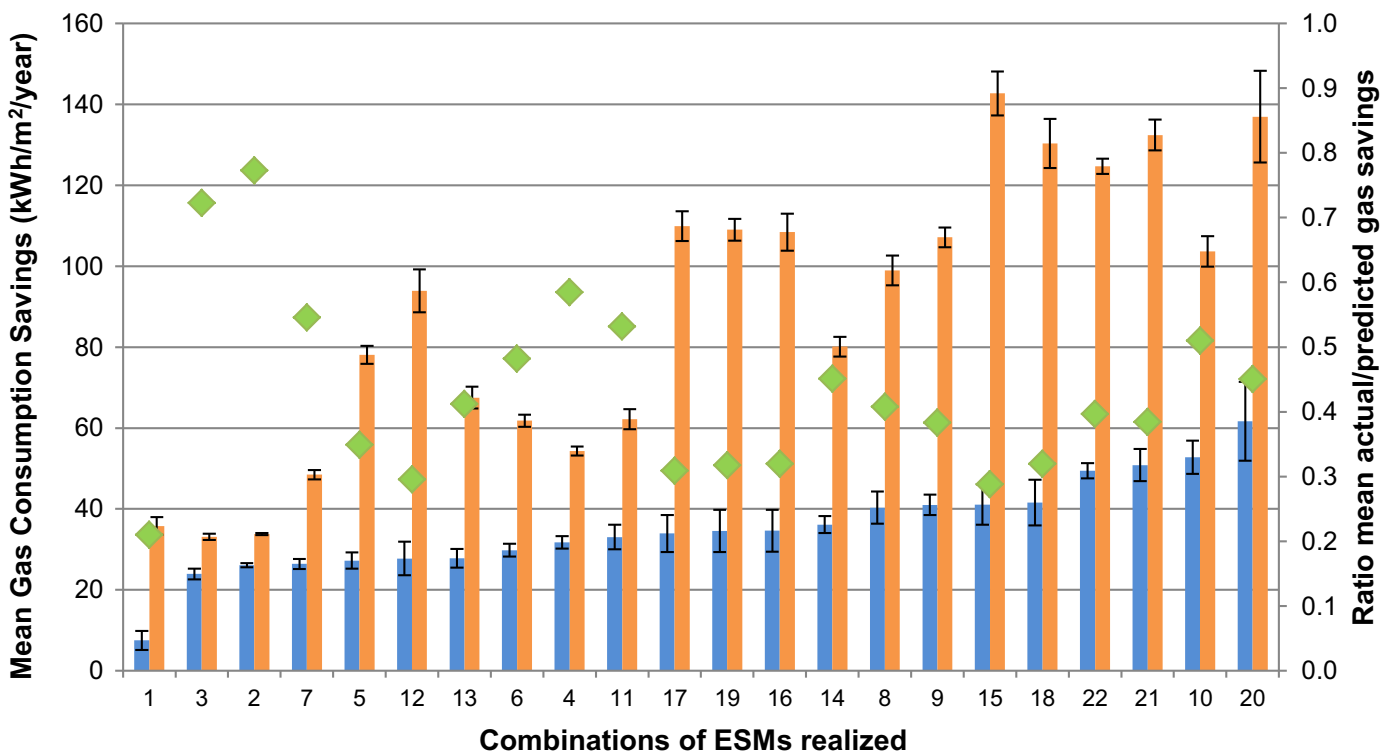

Fig. 6 Actual and predicted gas consumption savings for dwellings with combinations of ESMs realized

actual savings. This fact highlights the differences between the actual and the predicted gas consumption savings. Table 8 depicts how much can just the applied ESMs explain the savings and to what degree each ESM explains better the savings or has a larger effect compared to other ESMs.

\section{Conclusions}

The goal of this paper was to examine the impact of thermo-physical renovation measures on both the predicted and actual energy consumption of the renovated non- profit stock in the Netherlands. We focused on the actual savings as they can reveal the true effect of renovations on the reduction of energy consumption. The actual energy savings also highlighted the impact of the number and combinations of measures on the dwellings' performance. First, we analyzed the ESMs realized and then their impact on the actual and predicted energy consumption savings.

One of the main outcomes of this work is the fact that in the majority of renovated dwellings, either 1 or 2 ESMs have been realized $(78.2 \%$ of the renovated stock). This fact highlights the lack of deep renovations in the non-profit stock in the Netherlands. When 2 or more ESMs have been realized, the modeled savings are

Table 7 Index of frequent specific combinations of ESMs

\begin{tabular}{|c|c|c|c|}
\hline $\begin{array}{l}\text { Index of frequent } \\
\text { combinations of ESMs }\end{array}$ & Combinations of ESMs & Frequency & $\begin{array}{l}\text { Ratio mean actual/ } \\
\text { predicted savings }\end{array}$ \\
\hline ESM heating and glazing 01 & $\begin{array}{l}\text { Improved non-condensing boiler }(\eta=0.80-0.90) \text { to condensing boiler } \\
\quad(\eta \geq 0.95) \text { and double glass to HR+ glass }(1.95 \leq U<2.85)\end{array}$ & 1532 & 0.67 \\
\hline ESM heating and glazing 02 & $\begin{array}{l}\text { Improved non-condensing boiler }(\eta=0.80-0.90) \text { to condensing boiler } \\
\quad(\eta \geq 0.95) \text { and double glass to HR++ glass }(1.75 \leq U<1.95)\end{array}$ & 1369 & 0.61 \\
\hline ESM heating and ventilation 01 & $\begin{array}{l}\text { Condensing boiler }(\eta=0.90-0.925) \text { to condensing boiler }(\eta \geq 0.95) \\
\text { and natural ventilation to mechanical exhaust }\end{array}$ & 5435 & 0.73 \\
\hline ESM heating and ventilation 02 & $\begin{array}{l}\text { Condensing boiler }(\eta=0.925-0.95) \text { to condensing boiler }(\eta \geq 0.95) \\
\text { and natural ventilation to mechanical exhaust }\end{array}$ & 524 & 1.30 \\
\hline ESM heating and façade 01 & $\begin{array}{l}\text { Improved non-condensing boiler }(\eta=0.80-0.90) \text { to condensing boiler } \\
\quad(\eta \geq 0.95) \text { and no insulation façade to insulation }\left(1.36<R_{\mathrm{c}} \leq 2.86\right)\end{array}$ & 3462 & 0.45 \\
\hline ESM heating and façade 02 & $\begin{array}{l}\text { Condensing boiler }(\eta=0.90-0.925) \text { to condensing boiler }(\eta \geq 0.95) \\
\text { and no insulation façade to insulation }\left(1.36<R_{\mathrm{c}} \leq 2.86\right)\end{array}$ & 812 & 0.49 \\
\hline
\end{tabular}




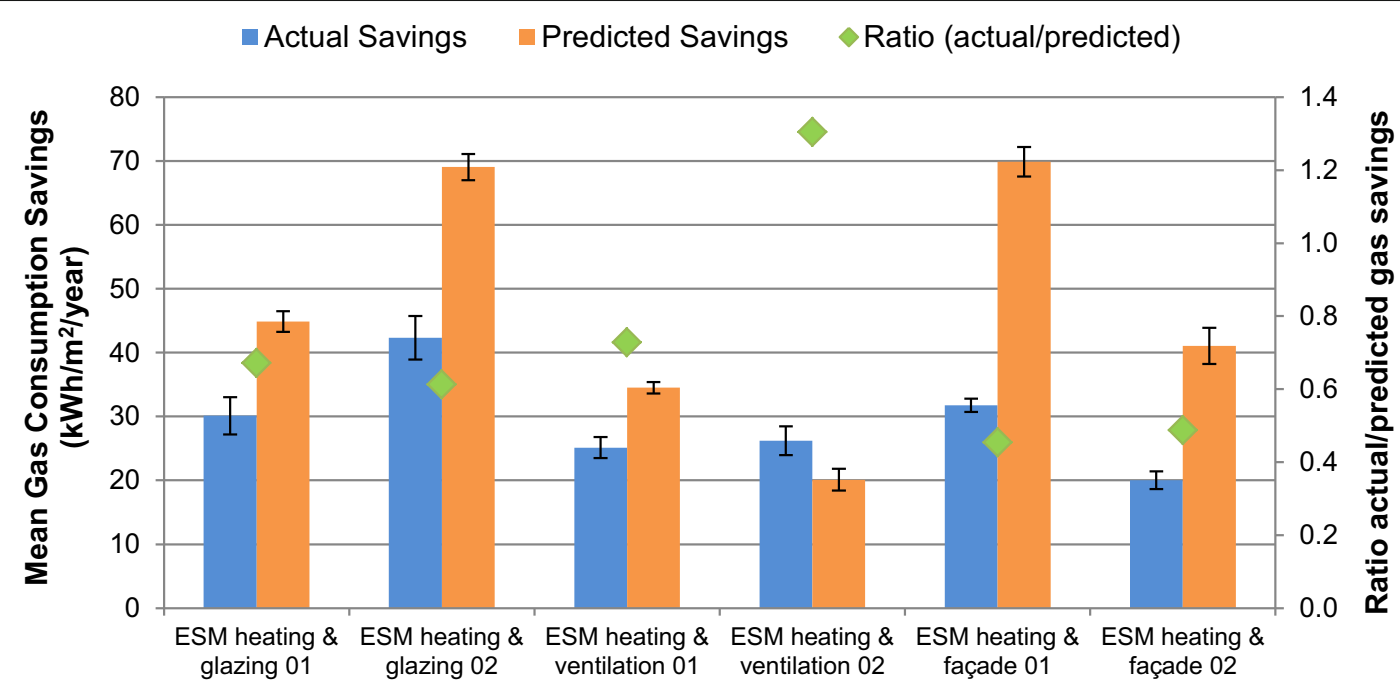

Specific combinations of ESMs realized

Fig. 7 Actual and predicted gas consumption savings for dwellings highlighting some of the most frequent combinations of ESMs realized over-predicted by $52 \%$ - compared to the actual savings - in the case of 2 ESMs, and by $163 \%$ in the case of 7 ESMs. As the number of measures increases, the gap between actual and predicted savings is also increasing. Moreover, we examined the non-renovated stock for the period 2010-2014. We found out that without any energy renovation taking place, a reduction of $11 \mathrm{kWh} / \mathrm{m}^{2} /$ year occurred. Several reasons can explain this reduction, such as possible changes in the method of calculations by the energy companies reporting to Statistics Netherlands (such as a difference of the LHV of the gas used), possible effects from occupant behavior change or mistakes in reporting in the SHAERE database that need further investigation.

When we examined the single ESMs, we concluded that the heating systems (space heating and DHW) and glazing are predicted better than the ventilation and insulation values. Furthermore, ESMs of the combined heating system and DHW and the glazing yield the highest actual gas savings. The ESM of ventilation was the most under-predicted. The reason for that is probably the assumed air flow rates of the model. In the combinations of ESMs, the results reveal that in most dwellings, standard renovations have been performed (2 ESMs usually) rather than deep renovations. As mentioned above, the gap between actual and predicted savings is larger when more ESMs are applied. Several reasons can be attributed to this effect. Predominantly, the assumed occupant behavior (including indoor temperature and hours of heating system operation) by the models used to predict the savings is a common factor causing the gap. However, falsely input envelope

Table 8 Multivariate linear regression analyses on the actual and predicted savings $\left(\mathrm{kWh} / \mathrm{m}^{2} /\right.$ year $)$

\begin{tabular}{|c|c|c|c|c|c|c|c|c|}
\hline & \multicolumn{4}{|c|}{ Actual savings $\left(R^{2}=1.6 \%\right)$} & \multicolumn{4}{|c|}{ Predicted savings $\left(R^{2}=27.5 \%\right)$} \\
\hline & $B$ & Std. error & Beta & Sig. & $B$ & Std. error & Beta & Sig. \\
\hline (Constant) & 8.987 & 0.241 & & $*$ & -5.947 & 0.187 & & $*$ \\
\hline ESM heating system vs. not changed & 10.584 & 0.313 & 0.089 & $*$ & 10.007 & 0.243 & 0.093 & $*$ \\
\hline ESM DHW vs. not changed & 5.247 & 0.305 & 0.044 & $*$ & 31.461 & 0.237 & 0.290 & $*$ \\
\hline ESM ventilation vs. Not changed & 1.910 & 0.269 & 0.014 & $*$ & 9.233 & 0.208 & 0.075 & * \\
\hline ESM glazing vs. not changed & 7.262 & 0.287 & 0.050 & $*$ & 24.708 & 0.223 & 0.188 & $*$ \\
\hline ESM roof vs. not changed & 7.979 & 0.331 & 0.048 & $*$ & 5.678 & 0.256 & 0.302 & $*$ \\
\hline ESM façade vs. not changed & 5.319 & 0.293 & 0.036 & $*$ & 31.709 & 0.227 & 0.238 & $*$ \\
\hline ESM floor vs. not changed & 5.014 & 0.303 & 0.033 & $*$ & 16.248 & 0.235 & 0.117 & $*$ \\
\hline
\end{tabular}

$*<0.001$ 
insulation variables, often based on the consumption year, is another issue raised by the results of this study. These falsely input variables can cause both under- and over-prediction of the actual energy savings. Further research on known cases where this has occurred would provide a more accurate insight into the degree that the phenomenon is responsible for the gap between actual and predicted energy savings.

The results of the regression analyses only revealed that the improvement ESMs alone do not explain the actual or predicted savings - the $R^{2}$ in both regressions was very low. However, our goal was not to create a model that would explain in the best form the actual and the predicted savings achieved. The change of the heating system and the glazing are affecting the actual savings more positively than other ESMs, based on the Beta coefficients. On the other hand, the ESM roof insulation, ESM façade insulation, and ESM DHW affect the predicted savings more than the rest of the ESMs. We have to keep in mind that these regression analyses were performed to better understand the effect of ESMs on the savings and not to provide explanations about the gap between actual and predicted savings. It is in the plans for future studies to include the state that a dwelling reaches after renovation and the interactions between the ESMs in the regressions to better understand the effect of combinations of ESMs and the different types of renovations (in terms of ambition) on the actual and predicted savings.

Another important lesson of this paper is the impact that collective agreements, like the Covenant of the nonprofit housing sector, can have on the uptake of energy renovations in the existing housing stocks. Data monitoring and the construction of SHAERE database have a prominent role to that respect. The gathering and analyzing of epidemiological data helps track renovations, energy savings, and the degree of implementation of current policies. The situation is, of course, not ideal as the monitoring can be further improved and the coupling with actual energy consumption can become standard practice. Moreover, the design of policies that can be implemented to promote energy renovations, the improvement of the quality of housing stocks, and the indoor air quality are of outmost importance for most of the EU countries and worldwide.

In conclusion, this paper showed the significance of the actual energy savings on understanding the impact of the number and combinations of measures applied to dwellings. The reality is far different from what is modeled at the time. This may be a demoralizing factor when housing associations take decisions to renovate or not parts of their stock. The predicted savings cannot be considered accurate with the current calculation models when compared to the actual savings. The main question to be answered by future research is how we can determine the effectiveness of ESMs and packages of ESMs if no actual energy savings are provided. Large statistical studies maybe the answer to providing more realistic energy saving values. Moreover, the connection of this results to policies applied or that will be in force in the future is of great importance.

Acknowledgements The authors would like to acknowledge Aedes for their support and provision of the SHAERE database.

\section{Compliance with ethical standards}

Conflict of interest The authors declare that they have no conflict of interest.

Open Access This article is distributed under the terms of the Creative Commons Attribution 4.0 International License (http:// creativecommons.org/licenses/by/4.0/), which permits unrestricted use, distribution, and reproduction in any medium, provided you give appropriate credit to the original author(s) and the source, provide a link to the Creative Commons license, and indicate if changes were made.

\section{References}

Aedes (2016). 〈https://www.aedes.nl/artikelen/bedrijfsvoering/ benchmarking/03-informatie-voor-corporaties/aedesbenchmark-2017-nieuwe-planning-voor-duurzaamheid-enhuurdersoordeel.html $\rangle$ (accessed 14 December 2016).

Balaras, C. A., Dascalaki, E. G., Droutsa, K. G., \& Kontoyiannidis, S. (2016). Empirical assessment of calculated and actual heating energy use in Hellenic residential buildings. [article]. Applied Energy, 164, 115-132. https://doi.org/10.1016/j.apenergy.2015.11.027.

Ballarini, I., Corgnati, S. P., \& Corrado, V. (2014). Use of reference buildings to assess the energy saving potentials of the residential building stock: the experience of TABULA project. Energy Policy, 68, 273-284. https://doi.org/10.1016/j. enpol.2014.01.027.

Boermans, T., Dinges, K., Grözinger, J., Schäfer, M., Förster, A., Hermelink, I., \& Manteuffel, B. V. (2015). Public consultation on the evaluation of directive 2010/31/EU Final Synthesis Report. Brussels: European Commission.

Boot P.A. (2009). Energy efficiency obligations in the Netherlands - a role for white certificates? ECN Report.

BPIE (Buildings Performance Institute Europe). (2011). Europe's buildings under the microscope: a country-by-country review 
of the energy performance of buildings. Brussels: Buildings Performance Institute Europe (BPIE).

BPIE (Buildings Performance Institute Europe). (2014). Renovation strategies of selected EU countries: a status report on compliance with Article 4 of the energy efficiency directive. Brussels: Buildings Performance Institute Europe (BPIE).

Braga, M., \& Palvarini, P. (2013). Social housing in the EU. Brusseles: Directorate General for Internal Policies.

BZK (Ministerie van Binnenlandse Zaken en Koninkrijksrelaties) (2014). Regeling van de Minister voor Wonen en Rijksdienst van 16 juni 2014. nr. 2014-0000293800. houdende vaststelling van regels voor het verstrekken van subsidie in verband met het stimuleren van de verduurzaming van de bestaande woningvoorraad in de sociale huursector (Stimuleringsregeling energieprestatie huursector). (In Dutch) 〈https://zoek.officielebekendmakingen.nl/stcrt-201417264.)

BZK (Ministerie van Binnenlandse Zaken en Koninkrijksrelaties) (2016a). Cijfers over Wonen en Bouwen 2016. (In Dutch). 〈https://www.rijksoverheid.nl/documenten/rapporten/2016 /04/11/cijfers-over-wonen-en-bouwen-2016.

BZK (Ministerie van Binnenlandse Zaken en Koninkrijksrelaties) (2016b). De rol van woningcorporaties op de woningmarkt - een WoON 2015-verkenning. (In Dutch). Retrieved from: 〈https://www.rijksoverheid. nl/binaries/rijksoverheid/documenten/publicaties/2016/04 /04/rapport-de-rol-van-corporaties-op-de-woningmarkt/ De+rol+van+woningcorporaties+op+de+woningmarkt++ definitief+v2.pdf. $\rangle$

Convenant Energiebesparing Huursector (2012). Retrieved from: https://www.rijksoverheid.nl/documenten/convenanten/2012 /06/28/convenant-huursector. Accessed 26 Feb 2018

ECN (Energy research Centre of the Netherlands) (2015). Energy efficiency trends and policies in the Netherlands. Report.-Part Odyssee MURE II Proj.

Elsinga, M., \& Wassenberg, F. (2014). Social housing in the Netherlands. In Social housing in Europe (pp. 21-40): John Wiley \& Sons, Ltd.

European Commission (2008). Communication "energy efficiency: delivering the 20\% target" COM (2008) 772 final. 〈http://eur-lex.europa.eu/LexUriServ/LexUriServ.do?uri= COM:2008:0772:FIN: EN:PDF $\rangle$ (accessed 9 April 15).

European Commission (2011). Communication from the Commission to the European Parliament, The Council, The European Economic and Social Committee and the Committee of the Regions: a quality framework for services of general interest in Europe. COM (2011) 900 final.

European Commission (2014). Financing the energy renovation of buildings with cohesion policy.

European Commission (2016a). Statistical pocketbook 2016. Retrieved from 〈https://ec.europa.eu/transport/factsfundings/statistics/pocketbook-2016_en〉 (accessed 27 March 2016).

European Commission (2016b). Impact assessment accompanying the document proposal for a directive of the European Parliament and of the council amending directive 2010/31/ EU on the energy performance of buildings.

European Parliament, Council of the European Union (2012). Directive 2012/27/EU of the European Parliament and of the Council of 25 October 2012 on energy efficiency, amending Directives 2009/125/EC and 2010/30/EU and repealing Directives 2004/8/EC and 2006/32/EC Text with EEA relevance.

Eurostat (2016). "Consumption of energy". Retrieved from: http://ec.europa.eu/eurostat/statistics-explained/index. php/Consumption_of_energy.

Filippidou, F., Nieboer N. and Visscher H. (2015).Energy efficiency measures implemented in the Dutch non-profit housing sector. In: Proceedings of the European Council for an Energy Efficient Economy (ECEEE) Summer School, pp. 979-989, Belambra Presqu'île de Giens, France, 1-6 June 2015.

Filippidou, F., Nieboer, N., \& Visscher, H. (2016). Energy efficiency measures implemented in the Dutch non-profit housing sector. Energy and Buildings, 132, 107-116. https://doi. org/10.1016/j.enbuild.2016.05.095.

Filippidou, F., Nieboer, N., \& Visscher, H. (2017). Are we moving fast enough? The energy renovation rate of the Dutch nonprofit housing using the national energy labelling database. Energy Policy, 109, 488-498. https://doi.org/10.1016/j. enpol.2017.07.025.

Galvin, R. (2014). Making the 'rebound effect'more useful for performance evaluation of thermal retrofits of existing homes: defining the 'energy savings deficit'and the 'energy performance gap'. Energy and Buildings, 69, 515-524.

Hamilton, I., Summerfield, A., Oreszczyn, T., \& Ruyssevelt, P. (2017). Using epidemiological methods in energy and buildings research to achieve carbon emission targets. Energy and Buildings, 154, 188-197.

ISSO (2009). ISSO 82.3 Formula Structure Publicatie 82.3 Handleiding EPA-W (Formulestructuur). (In Dutch).

Kemeny, J. (2002). From public housing soc market. Routledge.

Khoury, J., Hollmuller, P., \& Lachal, B. M. (2016). Energy performance gap in building retrofit: characterization and effect on the energy saving potential.19. Status-seminar «Forschen für den bau im kontext von energie und umwelt» Retrieved from http://archive-ouverte.unige.ch/unige:86086

Majcen, D., Itard, L. C. M., \& Visscher, H. (2013). Theoretical vs. actual energy consumption of labelled dwellings in the Netherlands: discrepancies and policy implications. Energy Policy, 54, 125-136. https://doi.org/10.1016/j. enpol.2012.11.008.

Majcen, D., Itard, L., \& Visscher, H. (2016). Actual heating energy savings in thermally renovated Dutch dwellings. Energy Policy, 97, 82-92.

Mastrucci, A., Baume, O., Stazi, F., \& Leopold, U. (2014). Estimating energy savings for the residential building stock of an entire city: a GIS-based statistical downscaling approach applied to Rotterdam. Energy and Buildings, 75, 358-367.

Mata, É., Kalagasidis, A. S., \& Johnsson, F. (2013). Energy usage and technical potential for energy saving measures in the Swedish residential building stock. Energy Policy, 55, 404- 414.

Meijer, F., Itard, L., \& Sunikka-Blank, M. (2009). Comparing European residential building stocks: performance, renovation and policy opportunities. Building Research \& Information, 37(5-6), 533-551. https://doi.org/10.1080 /09613210903189376.

Nieboer, N., \& Gruis, V. (2016). The continued retreat of nonprofit housing providers in the Netherlands. Journal of 
Housing and the Built Environment, 31(2), 277-295. https://doi.org/10.1007/s10901-015-9458-1.

Pombo, O., Rivela, B., \& Neila, J. (2016). The challenge of sustainable building renovation: assessment of current criteria and future outlook. Journal of Cleaner Production, 123, 88-100. https://doi.org/10.1016/j.jclepro.2015.06.137.

Priemus, H. (2013). The future of social housing. The Dutch case. International Journal of Co-operative Management, 6(2), $13-24$.

Rasooli, A., Itard, L., \& Ferreira, C. I. (2016). A response factorbased method for the rapid in-situ determination of wall's thermal resistance in existing buildings. Energy and Buildings, 119, 51-61.

RVO (Netherlands Enterprise Agency) (2011). Voorbeeldwoningen 2011 - Bestaande bouw. (In Dutch). 〈https://www.rvo.nl/sites/default/files/bijlagen/4.\%20 Brochure \% 20 Voorbeeldwoningen $\% 202011 \% 20$ bestaande\%20bouw.pdf).

RVO (Netherlands Enterprise Agency) (2015). Afgegeven energielabels woningen 2009-2014 Cijfers over Wonen en Bouwen. (In Dutch). 〈https://vois.datawonen. nl/jive/jivereportcontents.ashx?report=home_new $\rangle$.

Saheb, Y., Bódis, K., Szabó, S., Ossenbrink, H., \& Panev, S. (2015). Energy renovation: the trump card for the new start for Europe. European Commission - Joint Research Centre -
Institute for Energy and Transport, JRC Science and Policy Reports.

SER (2013). Energieakkoord voor duurzame groei. (In Dutch).

Sunikka-Blank, M., \& Galvin, R. (2012). Introducing the prebound effect: The gap between performance and actual energy consumption. Building Research \& Information, 40(3), 260-273.

Thomsen, A., \& van der Flier, K. (2002). Updating the housing stock. The Need for Renovation.

Tigchelaar C. (2014). Nulmeting subsidieregeling voor verhuurders. (In Dutch). 〈http://www.rijksoverheid. nl/documenten-en-publicaties/rapporten/2014/06/24 /nulmeting-subsidieregeling-voor-verhuurders.html $>$ http://www.rijksoverheid.nl/documenten-enpublicaties/rapporten/2014/06/24/nulmetingsubsidieregeling-voor-verhuurders.html $\rangle$.

Tigchelaar, C., Daniëls, B., \& Menkveld, M. (2011). Obligations in the existing housing stock: who pays the bill. In Proceedings of the ECEEE, (pp. 353-363).

Van Eck, H. (2015). Implementation of the EPBD in the Netherlands - status in November 2015. Neth. Ctry. Report. 2015, (Retrieved from 〈www.buildup.eu〉).

ürge-Vorsatz, D., Koeppel, S., \& Mirasgedis, S. (2007). Appraisal of policy instruments for reducing buildings' $\mathrm{CO} 2$ emissions. Building Research \& Information, 35(4), 458-477. https://doi.org/10.1080/09613210701327384. 